\title{
II. Abdülhamid Döneminde Dersim Sancağındaki İdari Yapı ve Ulaşım A $\breve{g}_{1}$ * Administrative Structure and Transportation Network in the Time of II. Abdülhamid in the Dersim Sanjak
}

\author{
İbrahim YILMAZÇELIK** - Sevim ERDEM***
}

Öz

Osmanlı Devleti, kurulduğu andan itibaren bayındırlı̆a ve özellikle de yollara önem vermiştir. Osmanlı tarafından inşa edilen yollar, daha önce Roma ve Bizanslilarda olduğu gibi, sadece fetih amaçlı değil daimi bir yol politikası olup, yolların güzergâhlarının belirlenmesinde askeri amaçlar kadar ticari menfaatlerde dikkate alınmıştır. Günümüz ulaşım ağının temeli, kervan yollarından oluşan daha eski bir sistemden gelişmiş olup bunun en azından 1920'li yillara kadar bu süreklilik arz ettiği bilinmektedir. Askeri amaçli yollar eski ve statiktir. Bu sebeple yol ağının değişiminde, ordu yollarından ziyade ticari kervan yolları daha önemlidir. Osmanlı döneminde askeri amaçl yollar oluştururken, eğer yeni bir yol ağı ise öncelikle yürüyüş talimatnamesi hazırlanır, eğer kullanıma uygun ise bu güzergâhtan geçiş kanunlaştırırdı. Askeri amaçlı yollar bilhassa padişahın sefere çıkacağı zamanlarda önem arz etmekteydi. Ancak Osmanlı Devletinin son dönemlerinde askeri amaçl yolların yapımında, sefer zihniyetinden ziyade eşklyalık olaylarını önleme ve ülke asayişini temin etme, temel esası oluşturmuştur.

Dersim sancağı, Doğu Anadolu'nun İç Anadolu ile birleştiği yerde oldukça arızalı bir bölge olup, güneyde Murat Suyu, batıda Karasu, kuzeyde Munzur siradağları ve doğuda ise Peri Suyu ile çevrilidir. Bölgenin coğrafi şartları, bu bölgede devletin tam manasıyla bir hâkimiyet kurmasına engel teşkil etmektedir. Bu bildirimizde, Osmanlı döneminde aşiretlerin yoğun olarak yaşadı̆̆ı Dersim bölgesindeki ulaşım ağı ile Dersim 'i çevreleyen Mamuratülaziz, Erzurum Vilayeti, Van Vilayeti ve Diyarbakır Vilayeti ile olan ulaşım bağlantısı da ortaya konulmaya çalışlacaktır.

Anahtar Kelimeler: Dersim, Sancak, Osmanl, Ulaşım, II.Abdulhamid

\section{Abstract}

Ottoman Empire had given importance to public Works and especially roads since its establishment. The roads built by the Ottoman, as in the Roman and Byzantine periods, were regarded not only as a way of conquering but also as a constant way policy, and financial benefits as well as military purposes were taken into consideration in the determination of the

Makale Geliş Tarihi: 07.06.2017 Kabul Tarihi: 18.09.2017

** $\quad$ Prof. Dr., Furat Üniversitesi, İnsani ve Sosyal Bilimler Fak., Tarih Bölümü,

E-posta: iycelik@hotmail.com

... Yrd. Doç. Dr., Bitlis Eren Üniversitesi, Fen-debiyat Fakültesi, Tarih Bölümü,

E-posta: sevimerdem23@hotmail.com

Akademik Bakış 223 
routes of the roads. The foundation of today's transportation network is more advanced than an older system composed of caravan roads and it is known to be so until at least 1920 s.

Military designed roads were old and static. Therefore, commercial caravan roads were more important than military roads in change of the road network. In Ottoman period while constructing military designed roads, if it was a new road network a walking instruction would be firstly prepared, if it was ready to use, transportation through the route would be enacted. Military designed roads were significant especially when padishah would set out. However, instead of military expedition, preventing banditry and guaranteeing the state security became important in construction of military designed roads in late periods of the Ottoman Empire.

The Dersim Sanjak being located in dangerous conjunction point of the Eastern Anatolia and the Middle Eastern Anatolia was covered by Karasu in the west, Munzur mountain ranges in the North and Peri Su in the east. The geographical conditons of the district prevented the state from dominating in this district. This paper aims to examine transportation network in the district of Dersim where tribes would live in Ottoman period and its transportational connection with Mamuratul-aziz, Erzurum Province, Van Province and Diyarbekir Province surrounding Dersim, as well.

Keywords: Dersim, Sanjak, Ottoman, Transportation, Abdulhamid II

\section{Giriş}

Yol, ülke imarını sağlamada bir vasıta olup, aynı zamanda ticaret, ziraat ve sanayinin gelişini sağlayan önemli bir araçtır. Ayrıca memleketin güvenlik ve asayişinin temininde de önemli bir yere sahiptir. Bir ülkede refah ve gelişmişlik düzeyinin iyi olabilmesi için iyi bir yol sistemi ağına sahip olmak gerekmektedir.

Osmanlı Devleti'nde, Kanuni Sultan Süleyman devrinden beri yolların gelişimine büyük bir önem verilmiştir. O zamanlardan beri Üsküdar'dan Ankara'ya ve Anadolu' nun çeşitli yerlerine ve Bağdat'a kadar ana yollar yapılmış ve bu yolların zaman içerisinde şubeleri de açılmıştır. Yollarla beraber hanlar, kervansaraylar, çeşmeler ve diğer mimarı yapılar da yol kavramı içerisinde yerini almıştır. Başa geçen her padişah kendi devrinde yeni yollar yaptırarak bu yol ağına katkıda bulunmuşlardır. Bu konudaki çalışmaların özellikle XIX. yüzyılın ikinci yarısından itibaren fazlalaştığını söylemek mümkündür. Mesela, Sultan Abdülmecid zamanına gelindiğinde, ıslah tedbirleri arasında, yollar önemli yer işgal etmiş ve bu amaçla çok sayıda memur görevlendirilmişti. Sultan II. Abdülhamid devri öncesi yol uzunluğu 3327 kilometre 643 metre iken, Sultan Abdülhamid'in tahta geçişinden itibaren, 1876-1878 yıllarındaki durgunluk haricinde, 2-3 yıl içerisinde yol konusunda önemli mesafeler kat edilmiş, gerekli önem ve ihtimam sayesinde 4.000 kilometre yol yapılmıştır .

Osmanlı Devleti, kurulduğu andan itibaren bayındırlığa olan ihtiyacı bilmekte ve bu doğrultuda hareket etmekteydi. Özellikle XIX. yüzyılın ikin-

1 Mecmua-ı Umur-u Nafia, H. Fi Muharrem 1302 (Ekim-Kasım 1884), s. 4. 
ci yarısında Osmanlı Devleti tarafından inşa edilen yollar, daha önce Roma ve Bizans'ta olduğu gibi, sadece fetih amaçlı değildi. Bu dönemde daimi bir yol politikası takip edilmişti. Yolların güzergâhlarının belirlenmesinde, askeri amaçlar kadar ticari menfaatler de dikkate alınmıştı². Bu çalışmada, Osmanlı devletinin son dönemlerinde Dersim Sancağı'ndaki ulaşım ağı ana hatları ile ele alınmıştır. Ancak bu dönemdeki ulaşım ağının ortaya konulabilmesi için Dersim bölgesinin, Osmanlı dönemindeki idari teşkilatlanmasının ana hatları ile bilinmesi lazımdır².

\section{Yüzyılın İlk Yarısına Gelinceye Kadar İdari Durum}

Doğu Anadolu Bölgesi'nde yer alan Tunceli; doğusunda Bingöl, batısında Malatya, kuzeyinde Erzincan, kuzey-doğusunda Erzurum, güneyinde Elazı ̆̆ illeri arasında kalan küçük bir vilâyettir. Bölgenin tarihî dönemler içerisindeki en eski yerleşim merkezleri, Hozat, Çemişgezek, Mazgirt, Pertek ve Sağman olup, tarihte bu bölgeler "Dersim" adıyla bilinmektedir". Esasında tarihî dönemler içerisinde Dersim iki mıntıkaya ayrılmıştır.

1. Batı Dersim: Hozat, Çemişgezek, Pertek, Ovacık, Kemah, Gürcanis ve Kuruçay kazalarını; 2. Doğu Dersim: Mazgirt, Kiğı, Çarsancak, Nazımiye ve Pülümür kazalarını kapsamaktadır 5 .

Bu bölge, Osmanlı hâkimiyetine geçtikten sonra, bölgenin Osmanlı hâkimiyetine geçmesinde önemli yardımları görülen mahallî beylerin bir kısım hakları korunmuştur ${ }^{6}$. Kanûnî devri başta olmak üzere bunu takip eden dönemlerde de "... ellerine verilen kadîm temessükler mûcebince..." denilerek "Yurtluk-Ocaklık “yoluyla sancak ve dirlik tasarruf edenlerin imtiyazları devam etmiştir. Devletin tanıdığı bu imtiyazlar Tanzimat dönemine kadar sürmüştür ${ }^{7}$. Dersim bölgesinin, Osmanlı hâkimiyeti sırasında Diyarbakır ve Erzurum Eyaletlerine bağlı olduğu görülmektedir. Bununla birlikte sancakların idarî statüleri Tanzimat'a gelinceye kadar geçen süre içerisinde sık sık değişikliğe uğramıştır ${ }^{8} .4$ Kasım

2 Mecmua-ı Umur-u Nafia, H. Fi Cemaziyel-ahir 1302 (Mart-Nisan 1885), s.198

3 Dersim Bölgesinin idari yapısı hakkında ayrıntılı bilgi için bkz. İbrahim Yılmazçelik, Osmanlı Devleti Döneminde Dersim Sancă̆l, Ankara, 2011, s.35-99. Bu makalede yer alan Dersim Sancağı'nın idari yapısına dair bilgiler de Osmanlı Devleti Döneminde Dersim Sancă̆ı, adlı eserdeki bilgilerin yeniden düzenlenerek verilmiş halidir.

414 Mayıs 1906 tarihli iradede, bu bölgeye Dersim adının niçin verildiği “... Dersim Sancağl’nın Dersim nâmıla mu'ayyen bir mevki’i olmayub aşâ'ir-i mevcûdenin (Dersimânll, Seyyidanlı ve Şeyh Hasanlı) nâmıyla münkasem olduğu üç şube'-i esâsiyeden en mühimmi olan Dersimânlı 'aşiretinin Kızılkilisa (Nazımiye), Mazgird, Ovacık ve Hozat kazaları satranç-vârî birer murabba' itibâriyle bu dört kazanın ittisâkı etrâfinda bir kıt'a-i sagîreden ibareten olan karargâhına nisbetle bu sancak o nâmı almış ve o kıt'a-i sagîreye el-yevm Dersim içi denilmekde bulunmuş olub ..." şeklinde açıklanmaktadır. BOA., Irade Dahiliye, 15.CA.1316, Hususi: 36.

5 Mehmet Zülfü Yolga, Dersim (Tunceli) Tarihi, (Yayına Hazırlayanlar: Ahmet Halaçoğlu, İbrahim Yilmazçelik), Ankara 1994, s.81-82.

6 Nazmi Sevgen, Doğu ve Güneydoğu Anadolu'da Türk Beylikleri, Ankara 1982, s.42.

7 Bayram Kodaman, Osmanlı Devrinde Doğu Anadolu'nun İdari Durumu, Ankara 1986, s.12.

8 Bilal Aksoy, Tarihsel Değişim Sürecinde Tunceli, Ankara 1985, s.183-189. 
1515 tarihinde Osmanlı idarî teşkilâtı içerisinde beşinci eyalet olarak Diyarbakır Eyaleti'nin teşkil edilmesiyle, bu bölgedeki topraklar Diyarbakır merkez olmak üzere teşkilâtlandırılmıştır ${ }^{9}$.

1516 tarihinde Pertek ve Sağman "Yurtluk-Ocaklık " sancak statüsü, Çemişgezek ise "Mülkiyet üzere " tevcih edilen sancak statüsü taşımakta olup, Diyarbakır Eyaleti'ne bağlıydı ${ }^{10}$. Pertek-Sağman ve Mazgirt sancakları, Diyarbakır Eyaleti'ne bağlı olma durumlarını XIX. yüzyılın ilk yarısı da dâhil olmak üzere sürdürmüşlerdir ${ }^{11}$. Çemişgezek sancağı, Çaldıran Savaşı'nı takiben Pir Hüseyin Bey'e tevcih edilmişse de, babası ve Çemişgezek'in eski hâkimi olan Hacı Rüstem Bey'in Çaldıran Savaşı'nda Şah İsmail saflarında Osmanlılara karşı savaşması sebebiyle, Pir Hüseyin evlâtlarına mülk olarak intikal etmemiş, sadece sancak dâhilindeki bazı zeametler mülkiyet üzere tasarruf edilmesi için evlâtlarına tevcih edilmişti. 1566 tarihinden sonra Çemişgezek Sancağı; Mazgirt, Sağman, Pertek ve Çemişgezek Sancağı olarak dört sancağa ayrılarak tekrar Pir Hüseyin Bey'in oğullarına tevcih edilmiştir ${ }^{12}$. Çemişgezek Beyliğinin dört sancağa taksim edilmesinden dolayı Çârsancak denilmiş ve bu isim daha sonra Pertek Kazası'na âlem olmuştur ${ }^{13}$. Bu arada Çemişgezek Sancağı'nın "mülkiyet üzere" sancak olma statüsü 1565-1566 tarihleri arasında sona ermiş ve bu tarihten sonra bu sancak klâsik Osmanlı sancağı haline getirilmiştir ${ }^{14}$.

Kuzican (Pülümür) Sancağı da başlangıçta “ Ocaklık " statüsünde iken, daha sonra klâsik sancağa dönüştürülmüştür. Bu arada tarihî dönemlerde Dersim mıntıkası içerisinde adı geçen, Kemah, Kuruçay, Gürcanis kazalarıyla birlikte Kuzican Sancağı da idarî taksimatta uzun bir dönem (XVI. yüzyıl-XIX. yüzyıl) Erzurum Eyaletine bağlı olmuştur ${ }^{15}$. XVI. ve XIX. yüzyıla ait idarî taksimata bakıldığında, bazı tarihlerde Çemişgezek ve Sağman sancakları da Erzurum Eyaleti'ne bağlı görülmektedirr ${ }^{16}$. Bununla birlikte özellikle Çemişgezek ve Sağman'ın ekseriyetle Diyarbakır Eyaletine bağlı olduğu tespit edilmiştir ${ }^{17}$.

XIX. yüzyıla girerken Dersim mıntıkası içerisinde zikredilen Çarsancak, Çemişgezek, Karaçor, Gürcanis ve Kuruçay kazaları ile ilgili olarak bir mesele daha ortaya çıkmıştır. Bu da 1775 tarihinde Maden-i Hûmâyûn Emanetinin kurulması ile bu kazaların idarî statülerinde baş gösteren karışıklıktır ${ }^{18}$. 1775

Cilt 11

Sayı 21

Kış 2017

9 İbrahim Yılmazçelik, XIX. Yüzyllın İlk Yarısinda Diyarbakır, Ankara 1995, s.8.

10 M. Ali Ünal, XVI. Yüzyllda Harput Sancağl, Ankara 1989, s.33.

11 Yılmazçelik, XIX. Yüzyllın İlk Yarısında Diyarbakır, s.124-134.

12 Ünal, XVI. Yüzyılda Harput Sancağı, s.33.

13 Şeref Han, Şeref-nâme, Çev. Mehmet Emin Bozarslan, İstanbul 1975, s.194. Ayrıca bkz. Mehmet Zülfü, Dersim Tarihi, s.54-55.

14 Metin Kunt, Sancaktan Eyalete, İstanbul, 1978, s.36-37. Ayrıca bkz. Ünal, XVI. Yüzyılda Harput Sancă̆l, s.33.

15 Kunt, Sancaktan Eyalete, s.36-37.

16 Baykara, Anadolu'nun Tarihi Coğrafyasına Giriş I, s.99-104.

17 İ.Yılmazçelik, XIX. Yüzyllın Illk Yarısında Diyarbakır, s.124-134.

18 Fahrettin Tizlak, Keban ve Ergani Yöresinde Madencilik, Fırat Ün. Sosyal Bil. Ens. Yayınlanma- 
yılından önce Keban Madeni'ne kömür ve kütük temin etme, Maden idaresine sermaye teşkil etmek üzere vergi vermek zorunda olan sancaklar arasında Kemah, Kuruçay, Gürcanis ve Çarsancak sancaklarının da adı zikredilmektedir ${ }^{19}$. Söz konusu kazalar idarî açıdan Diyarbakır Eyaletine, malî açıdan ise Maden Eminliğine bağlı idi. Osmanlı döneminde idari alanda görülen bu karışıklık, XIX. yüzyılın ikinci yarısında düzeltilmeye çalışılmıştır.

\section{Yüzyılın İkinci Yarısında İdarî Taksimat}

Tanzimat Fermanı'nın ilân edilmesiyle Osmanlı Devletinde ülke genelinde idarî, malî ve sosyal alanda bir kısım düzenlemeler yapılmıştır. Bununla birlikte Tanzimat Fermanı'nın ilânından hemen sonra, yönetimde yapılan yenilikler ülkenin her tarafında aynı zamanda uygulanamamıştır. XIX. yüzyılın ilk yarısına kadar geçen süre içerisinde, Dersim olarak adlandırılan bölgedeki bir kısım sancaklar, fazla önemi olmayan küçük yerleşim birimleriydi. Bu yerlerdeki yönetimde yapılan yenilikleri ise başlangıçta Diyarbakır Eyaleti içerisinde ele almak lâzımdır. Bu cümleden olmak üzere, Diyarbakır Eyaleti'nin Tanzimat'a dâhil edildiği Mart 1845 tarihinden sonra, Dersim mıntıkasında da bir kısım idarî düzenlemelerden bahsedilebilir ${ }^{20}$.

Diyarbakır Eyaletinin 1845 tarihinde Tanzimat'a dâhil edilmesiyle ülke genelinde yapılmak istenen bir kısım uygulamalar, bu bölgede de tatbik edilmeye çalışılmıştır. Ancak bunu uygulamak, özellikle Yurtluk ve Ocaklık olarak bölgede toprak tasarruf edenlerin muhalefeti ile karşılaştığından kolay olmamıştır. Osmanlı, Tanzimat sonrasında, Dersim bölgesini idarî açıdan yeni bir düzenlemeye tabii tutulmuştur. Osmanlı Devleti'nin bu bölgede 1848 yılından itibaren uygulamaya çalıştığı düzenlemeler ise aşiretlerin muhalefeti ile karşılaştığından, uzun bir müddet bölgede tam bir istikrar sağlanamamıştır ${ }^{21}$.

Bölgede Tanzimat sonrası yapılan en önemli değişiklik 1845 yılında Harput Sancağı ve Maden-i Hûmâyûn Emanetinin, Diyarbakır eyaletinden ayrılarak bir müddet sonra Harput Eyaletinin teşkil edilmesidir ${ }^{22}$. 20 Eylül 1845 tarihli bir fermandan anlaşıldığına göre, Harput ve Maden-i Hûmâyûn Emanetine bağlı bazı kazalar, Diyarbakır Eyaletinden ayrılarak ayrı bir mutasarrıflık teşkil edilmiştir ${ }^{23}$. Bu tarihten kısa bir süre sonra 1 Nisan 1846 tarihinde Harput müstakil bir eyalet haline getirilmiştir. Bu tarihten sonra Dersim, Harput Eyaletine bağlanmış olmalıdır.

Gory
Akademik
Bakış
227
Cilt 11
Sayı 21
Kış 2017

mış Doktora Tezi, Elazı̆̆ 1991, s.25-31.

19 Tizlak, Keban ve Ergani Yöresinde Madencilik, s.45.

20 Yılmazçelik, XIX. Yüzyılın İlk Yarısında Diyarbakır, s.182.

21 Musa Çadırcı, “ Tanzimat’ın Uygulanması ve Karşılaşılan Güçlükler (1840-1856) “,Mustafa Reşid Paşa ve Dönemi Semineri Bildiriler, Ankara 1985, s.99-101.

22 İbrahim Yılmazçelik, “1840-1850 Yıllarında Harput”, Türk Dünyası Araştırmaları Dergisi, Sayı: 52, s. 125.

23 BOA., Cevdet Dahiliye, No:13142. 
Dersim Sancağı'nın kesin olarak hangi tarihte oluşturulduğu konusunda elimizde belge yoktur. Bu konudaki tek bilgi H. 1310 (1892-1893) Ma'mûretü'lAzîz Salnâmesindeki kayıttır. Buradaki bilgilerde; “... Dersim Mutasarrıflığının makarr-ı merkezi vilayete (Harput) 12 saat mesafede kâîn Hozat kasabası olup adî bir karye iken Dersim'ce Mebde-î Islahât olan 1264 (1847-1848) senesinde 'asâkir-i şahânenin vürûduyla bir kışla te'sîs ve o sırada Dersim Sancağı nâmıyla mutasarrıflı teşkil ..."edildiği belirtilmektedir ${ }^{24}$. Ancak Dersim Sancağı büyük bir ihtimalle 1848 tarihinde kurulmuş olmalıdır. Zira aynı tarihlerde Diyarbakır Eyaleti'nin idarî taksimatında da önemli değişiklikler yapılmıştır ${ }^{25}$. Bu tarihten sonra Dersim Sancağı, Harput Eyaleti'ne bağlanmıştır.24 Nisan 1849 tarihli Dersim Sancağı'na kaymakam tayini ile ilgili bir iradeden, Dersim Sancağı kaymakamı İbrahim Bey’in “... Har put Eyaleti meclis-i kebîrinden bi't-tanzim Harput valisi devletlü Paşa hazretleri tarafindan bâ- tahrîrât irsâl kıllınan mazbata ..." doğrultusunda atandığı anlaşılmaktadır ${ }^{26}$.

Dersim Sancağı'nın teşkil edildiği 1848 tarihinde sancak merkezi Hozat yapılmıştır ${ }^{27} .8$ Ocak 1849 tarihli bir lâyihadan anlaşıldığına göre, Ovacık nâm mahalle bir kışlanın yapılması istenmiş ve bunun masraf defterleri gönderilerek kabul edilmişti ${ }^{28}$. Ancak 14 Mayıs 1849 tarihinde Anadolu Ordusu Müşiri tarafından yazılan bir arzda "... Ovacık nâm mahalle bir bâb kışlanın inşası mûktezâa-yı irâde-i seniyye ise de oranın havası gayet kötü..." olduğundan bahisle bundan vazgeçildiği belirtiliyordu. Söz konusu arzda, Ovacık'ın havasının sert olduğu ve askerin bundan perişan olduğu belirtilerek, kışlanın suyu ve havası çok daha iyi olan Hozat'a yaptırılması istenmiştir ${ }^{29}$. Nitekim söz konusu kışla 1850 tarihlerinde yaptırılmıştır ${ }^{30}$

Dersim Sancağı 1848 tarihinde teşkil edilmiş ve Harput Eyaletine bağlanmıştı. Ancak 13 Kasım 1848 tarihli bir tahrirat hülâsasından anlaşıldığına göre, Dersim Sancağı'nın Diyarbakır veya Harput eyaletlerinden birisine bağlanması istenmekteydi. 13 Kasım 1848 tarihli bu tahrîrat hülasasında, Dersim, Kuzican ve Mazgirt'in büyük yerler olduğu belirtiliyor ve bunların Koçgiri aşiretiyle birleştirilip toptan bir sancak itibariyle kaymakamlık olarak idaresinin uygun görüldüğü bildiriliyordu. Bununla birlikte Koçgiri ile Dersim arasında yer alan ve Maden-i Hûmayun kazalarından Kemah, Gürcanis ve Kuruçay ka-

24 H. 1310 Tarihli Ma'mûretü'l-Azîz Salnamesi, s.242. Ayrıca bkz. H. 1312 Tarihli Ma'mûretü'l-azîz Salnamesi, s.227.

25 Aralık 1847 Tarihinde Diyarbakır Eyaletinin idarî taksimatındaki değişiklik ile Diyarbakır başta olmak üzere, yeni eyalet Van, Muş, Hakkâri Sancakları, Cizre, Bohtan ve Mardin kazalarından oluşmaktaydı. Ayrıntılı bilgi için bkz. İbrahim Yılmazçelik, “1840-1850 Yıllarında Harput”, s.138.

26 BOA., Irade Meclis-i Vâlâ, No:18357.

27 BOA., Irade Dâhiliye, No: 13263.

28 “... Ovacık Harput Eyâletiyle Erzurum Eyâletinin vasatında vâk̂̂̀' olmasılyla orada dâ '̂̀ma mikdâr-l kâfì 'asker bulunması lâzımeden ve bu cihetle kışla icâb ideceği ...". "...Ovacık nâm mahalle 800 kîse mikdarı mesârifiyle iki taburluk kargîr bir kışlanın inşâsıyla...”. BOA., Irade Meclis-i Vâlâ: No: 3542

29 BOA., Irade Dahiliye, No: 11639.

30 Mehmet Zülfü, Dersim Tarihi, s.91. 
zalarının, Koçgiri ile Dersim'in birleştirilmesine engel görüldüğünden söz konusu kazaların Dersim Sancağı'na iltihak ettirildiği bildirilmekteydi. İşte ortaya çıkan bu yeni duruma göre, Dersim Sancağı' nın Diyarbakır veya Harput eyaletlerinden birisine bağlanması istenmekteydi ${ }^{31}$. Nitekim bu görüş doğrultusunda Dersim Sancağı bir müddet Diyarbakır Eyaletine bağlanmış ise de ${ }^{32}$, bu oldukça kısa sürmüş ve 6 Temmuz 1851 tarihinde çıkan bir irade ile Dersim Sancağı, -Harput'a daha yakın olması sebebiyle- yeniden Harput Eyaleti'ne dâhil edilmiştir ${ }^{33}$.

Aşiretlerin kaza teşkil edilmelerine dair uygulamalar, Osmanlı idarî yapısı içerisinde bilinen bir uygulamadır ${ }^{34}$. Nitekim 1848 tarihinden sonra Dersim Sancağı' na bağlı Koçgiri aşireti de kaza kabul edilerek, vergilendirme yoluna gidilmiştir. 1842 tarihinden sonra ülke yönetiminde Sancak-Kaza biçiminde yeni bir idarî düzenlemeye gidilmiş ve muhasıllığın kaldırılmasıyla Kaza Müdürleri oluşturulmuştur. Bu tarihten sonra kaza tabiri idarî bir birim olarak şekillenmiş, sancak merkezlerinde kaymakamlar, diğer kazalarda ise kaza müdürleri ilk plâna çıkmıştır. 1848 tarihinden sonra Dersim merkez kazasına kaymakam ve diğer kazalara ise müdürler tayin edilmişti. Bu arada kaza itibar edilen Koçgiri Aşireti'ne de müdür tayin edilmiştir ${ }^{35}$.

1848-1851 tarihleri arasında Dersim Sancağı'nın idarî taksimatı şöyledir:

Dersim (Hozat) Sancağı, Gürcanis Kazası, Kuruçay Kazası, Ovacık Kazası, Mazgird Kazası, Kuzican Kazası, Koçgiri Kazası (Aşiret), Kemah Kazası ${ }^{36}$ Bu idarî taksimattan da anlaşılacağı üzere, Dersim Sancağı içerisinde olması icap eden Çarsancak Kazası bu tarihlerde, Harput Eyaletine bağlı Maden-i Hümayun Sancağına dâhildi. 16 Haziran 1852 tarihli Dersim kaymakamlığı ve asker maddelerine dair bir arzdan anlaşıldı̆̆ına göre bu tarihte, “... Dersim Sancağı'nın hüsn-i idare ve inzibâtı zımnında ve kurb ve civâr olan Çarsancak Kazası livâ-i mezbûra ilâve ..." olunmuştur ${ }^{37}$. Yine bu dönemde Çemişgezek Kazası da Harput'a bağlı sancaklar arasındadır.

1851-1867 tarihleri arasında ise Dersim Sancağı'nın idari taksimatı şöyle şekillenmişti ${ }^{38}$. Dersim (Hozat) Sancağı, Kuruçay Kazası, Gürcanis Kazası, Çar-

31 BOA., A. MKT, MVL, Dosya: 10, Sira: 85.

32 BOA., Irade Meclis-i Vâlâ, No: 5817.

33 BOA., Irade Meclis-i Vâlâ, No: 7106.

34 Türk göçebe hayatının bir sonucu olarak ortaya çıkan bu uygulamalar hakkında bkz. Yılmazçelik, XIX. Yüzyllın Illk Yarısinda Diyarbakır, s.128-129.

35 BOA., Irade Meclis-i Vâlâ No: 3957. Koçgiri kazası hakkında ayrıca bkz. BOA., Irade Meclis-i Valâ, No: 5817.

36 BOA, D. CRD, Genel: 40719, Özel: 848; ML.VRD, No: 2335, Cevdet Dahiliye, No: 14542, İrade Dahiliye, No: 13263, Irade Meclis-i Vâlâ, No: 20503, Irade Mevadd-ı Dahiliye, No: 39457.

37 BOA., Irade Meclis-i Vâlâ, No: 8431.

38 BOA., Maliyeden Müdevver, No: 13190; ML-VRD, No: 3057; Irade Meclis-i Vâlâ, No: 11388, No: 13735; Irade Dahiliye, No: 23611; No: 28195. Irade Meclis-i Vâlâ, No: 18501, No: 19229. Cevdet Maliye No: 9377. Ayrica bkz. H. 1273 Devlet Salnamesi, Nakleden: Tuncer Baykara, Anadolu'nun

Akademik Bakış 229 Cilt 11 Sayı 21 Kış 2017 
sancak Kazası, Koçgiri Kazası (Aşiret), Kemah Kazası, Ovacık Kazası, Mazgird Kazası, Kuzican Kazası. Bu tarihler arasında da Çemişgezek Harput Sancağı'na bağlıydı.

1851-1867 tarihleri arasında da Dersim Sancağı, Harput Eyaleti'ne bağlıyd1 ${ }^{39}$. Ancak bu tarihte sancak merkezi Kemah Kazası'na kaydırılmıştı. 17 Mart 1855 tarihli bir arzda "... Ovacık ve Çarsancak kazalarında bu aralık asâkir-i nizamiye olmadığından ve Kemah Kazası'nın makarr- kaimmakamî ittihâz kılınmasından nâş̂ิ ..." şeklinde geçen ifade, sancak merkezinin bu tarihlerde Hozat'tan, Kemah'a kaydırıldığını doğrulamaktadır ${ }^{40}$.

5 Ocak 1858 tarihli bir tahrîrattan anlaşıldığına göre, bu tarihte Hozat'ta bulunan kışla ve kaymakam konağının tamirleri tamamlanmış ve Harput'ta bulunan Piyade Birinci Alay Birinci tabur, Birinci şişhaneci taburundan üç bölük asker ve iki top Hozat'a gönderilmiştir ${ }^{41}$. 1859 tarihinde bu sefer Dersim Sancağı'nın merkezi Ovacık Kazası olmuştur. 4 Mart 1859 tarihli bir belgede “... Dersim Sancağı'nın makarrı bulunan Ovacık Kazası ..." tabiri ${ }^{42}$ ayrıca H. 1276 (1860$1861)$ tarihli Dersim Sancağı Masraf Defterinde geçen "Kaza-i Ovacık Re's-i Liva “ tabiri bunu doğrulamaktadır ${ }^{43}$. Dersim Sancağı'nda 1848 tarihinden itibaren yerleştirilmeğe çalışılan yeni düzenlemeler 1867 tarihlerinde sonuç vermeğe başlamıştır. Nitekim 23 Temmuz 1867 tarihli bir İrade'de Kuzican (Pülümür) Kazası'nda nüfus sayımının tamamlandığı, Mazgird ve Ovacık kazalarının ise sayım için memur istedikleri kayıtlıdır ${ }^{44}$.

1867 yılında Ma'mûretü'l-Azîz Eyaleti, Diyarbakır Eyaletine bağlanarak, sancak haline getirilmiştir ${ }^{45}$. Ma'mûretü'l-Azîz Sancağı 1875 tarihinde ise yapılan yeni idarî düzenleme ile Diyarbakır Eyaletinden ayrılarak müstakil bir mutasarrıflık haline getirilmiş, 1878 tarihinde ise tekrar Vilayet haline getirilmiştir. 1867-1878 tarihleri arasında Dersim Sancağı'nın idarî durumunda ise şu değişiklikler tespit edilmiştir: 1864-1867 yılları arasında yeni bir idarî düzenlemeye gidilmiş, 1864 sonlarında idare-i Vilâyet Kanunu çıkmıştır ${ }^{46}$.

1867 tarihli Vilâyet Nizamnamesine göre; Çarsancak, Ovacık, Mazgirt ve dı ${ }^{47} .23$ Temmuz 1867 tarihli Dersim kazalarında tahrîr-i nûfûsa dair, Erzurum

\section{Tarihi Coğrafyasina Giriş I, Ankara 1988, s.255 - 256.}

40 BOA., Irade Meclis-i Vâlâ, No: 15294. 23 şubat 1859 tarihli bir arzdan da sancak merkezinin Hozat olmadığı anlaşılmaktadır. “... Dersim Sancağında kâ 'in Hozat nâm mahallin muahharen dahî makarr-ı kaimmakamî ittihâz kulınmasından dolayl ...”. bkz. BA., Irade Meclis-i Vâlâ, No: 18363.

41 BOA., Irade Dahiliye, No: 26038.

42 BOA., Irade Meclis-i Vâlâ, No: 18061.

43 BOA., Cevdet Maliye, No:9377.

44 BOA., Irade Mevadd-ı Dahiliye, No: 39457.

45 H. 1301 Tarihi Ma'mûretü'l-azîz Salnamesi, s.97.

46 Baykara, Anadolu'nun Tarihi Coğrafyasina Giriş I, s.130.

47 Vecihi Tönük, Türkiye'de İdari Teşkilatın Tarihi Gelişimi ve Bugünkü Durumu, Ankara 1945, s.166. 
Valisi Mustafa Paşa tarafından Sadaret makamına yazılan bir arzdan da, bu tarihte Kuzican, Mazgird, Ovacık ve Çarsancak kazalarının Erzincan Sancağı'na bağlı olduğunu tespit etmek mümkün olmaktadır ${ }^{48}$. Bu sırada Dersim bölgesinde olan diğer kazalar, Ma'mûretü'l-Azîz Sancağı ve dolayısıyla Diyarbakır Eyaleti'ne bağlıdır.

İdarî sahadaki bu bölünme Dersim Vilayeti'nin teşkil edildiği 1880 tarihine kadar devam etmiştir. 1880 tarihinde Dersim; Hozat merkez olmak üzere vilâyet teşkil edilmiştir. 1848 tarihinde Dersim Sancağı'nın merkezi olan Hozat, sancak merkezinin buradan kaydırılmasıyla tekrar eski haline dönmüştü. Ancak 1880 tarihinde yeni teşkil edilen Dersim Vilâyeti'nin merkezi olduktan sonra Hozat'ta birçok yeni ev 2 hamam ve 5 kahvehaneye ilâve olarak, 1 cami ve bir de Rüşdiye mektebi yaptırılmıştır ${ }^{49}$.

1880 tarihinde Dersim Vilâyeti'nin ilk valisi Fikri Paşa'dır. Bu tarihte Dersim Vilâyeti'nin idarî taksimatı şöyledi ${ }^{50}$. Dersim (Hozat) Vilâyet, Mazgird Sancak, Kızılkilise (Nazımiye) Kazası, Pah Kazası, Çarsancak Kazası, Çemişgezek Kazası, Ovacık Kazası.

Dersim Vilâyeti yaklaşık olarak on sene kadar devam etmiş, ancak 13 Mayıs 1888'de "vilâyet umûmî ve husûsî varidatı teşkilâtı masrafını bile korumadı̆̆ından", aynı tarihte lağvedilerek, Mutasarrıflık olarak Harput Vilâyeti'ne bağlanmıştır ${ }^{51}$. 1888 tarihinde Hozat merkez olmak üzere Dersim; Çarsancak, Mazgird, Kızılkilise, Kuzican, Ovacık, Hozat, Pertek, Çemişgezek, Pah kazalarından oluşmaktaydı ${ }^{52}$. Dersim bu tarihten itibaren, Osmanlı Devleti'nin yıkılışına kadar geçen süre içerisinde “ Mutasarrıflık “ olarak, Ma'mûretü'l-AzîzVilâyeti'ne bağlı kalmıştır.

1892 tarihinde Dersim Sancağı, Harput'a bağlı bir sancak olup, mutasarrıflıkla idare edilmekteydi ${ }^{53}$. Yine bu tarihte Dersim Sancağı; Hozat, Çemişgezek, Çarsancak, Kuzican, Mazgird, Pah, Ovacık ve Kızılkilise (Nazimiye), kazalarından oluşmaktayd $1^{54}$. Bu tarihten sonra bölgede nahiye teşkilâtı da kurulmaya

48 BOA.,Irade Mevadd-ı Dahiliye, No: 39457.

49 H. 1310 Tarihli Ma'mûretü'l-Aziz Salnamesi, s.242-243. H. 1312 Tarihli Ma'mûretü'l-Aziz Salnamesi, s.227-228.

50 Mehmet Zülfü, Dersim Tarihi, s.91.

51 Dersim, T.C. Dâhiliye Vekâleti Jandarma Umum Kumandanlığı III, IKS-Sayı: 55058, s.57

52 Dersim, T.C. Dahiliye Vekâleti, s.57, Ayrıca bkz. Şemsettin Sami, “ Dersim “, Kamûsü’l-Alâm, C. III, İstanbul, 1307, s.2131-2132.

53 H. 1310 Tarihli Ma'mûretü'l-Azîz Salnamesi, s.121.,Şemsettin Samî, a.g.e., s.2131-2132.

54 Nâzımiye kazası daha önce Kızılkilise adını taşımaktaydı. 1908 tarihinde orada kaymakam bulunan Balıkesirli Mehmed Vehbi Efendi’nin, “ Kızılkilise nâm menhûsunun tahvîli hakkında ma'rûzât-1 sâbıkanın henüz eseri görülmedi. Lütfen menfa'at-1 vatan nâmına is'afına müsâ'ade buyurularak, tervîh-i mutallib için hafîd-i nevzâd-1 padışahî Nazım Efendi nâmına ve bi'l-âhiren isbet edilmesine delâlet-i vefîkadan devletleri merhametine, fî 25 kânun-1 sânî sene 326 (7 Şubat 1911) “ şeklinde gönderdiği telgıraf üzerine bu kazanın adı Nâzımiye’ye çevrilmiştir. bkz.Mehmed Zülfü, Dersim Tarihi, s.94.

Akademik Bakış 231 Cilt 11 
başlamıştır. Nitekim 1892 tarihinde Pertek nahiyesi, Çarsancak Kazası'na bağlıydı ${ }^{55}$. Ancak 1892 yılının sonlarına doğru bazı Önemli değişiklikler yapılmıştır.

19 Eylül 1892 tarihinde Ovacık ve Pah kazaları lağvedilmiş, Kuzican Kazası, Erzincan Sancağına bağlanmıştır. Bu yeni düzenleme ile Dersim Sancağı Hozat merkez olmak üzere, 1-Çemişgezek, 2- Çarsancak, 3- Mazgird kazalarından ibaret kalmıştır. Yine aynı tarihte Dersim Mutasarrıflı̆̆ı, Dersim Kumandanlığı ile birleştirilerek, " Dersim idare-i mülkiyesi “ bu havaliyi iyi bilen Erzincan Redif Mirlivası Ali şefik Paşa'ya askerî kumandan olarak tevcih edilmiştir ${ }^{56}$.

Dersim Sancağı'nın idaresinin askerî kumandana ihalesi de fazla uzun sürmemiş ve Ali Şefik Paşa 30 Kasım 1892 tarihinde görevinden alınarak, idare mutasarrıflık şeklinde sürdürülmüştür ${ }^{57}$. Öte yandan idarî sahadaki düzenlemeler de hemen oturmamıştır. Zira H. 1312 (1894-1895) tarihli kayıtlarda daha Önceden kaldırıldığı bildirilen Pah ve Ovacık kazalarıyla, Erzincan sancağına bağlandığı belirtilen " Kuzican nâm-ı diğer Pülümür "Kazası 1894-1895 tarihlerinde Dersim Sancağı'na bağlı görünmektedir. Buna göre 1894-1895 tarihleri arasında Dersim Sancağı Ma'mûretü'l-Azîz sancağına bağlı olup, şu kazalardan meydana gelmekte idi' ${ }^{58}$ : Merkez (Hozat) Kazası, Çemişgezek (Ovacık buraya bağl1) ${ }^{59}$, Çarsancak Kazası, Mazgird Kazası, Kuzican (Pülümür), Kızıl Kilise (Nazımiye) Kazası, Pah Kazası.

Bununla birlikte daha sonraki kayıtlardan anlaşıldığına göre, yukarıda verilen bilgiler, 1892 tarihinden önceki idarî uygulamayı yansıtmaktadır. Nitekim 14 Mayıs 1906 tarihli bir iradede, Dersim Sancağı'nın sınırları “...Erzincan Sancağının merkez ve Kuzican ve Erzurum'un Kiğı ve Diyarbakır'in Palu ve Ma'mûretülAzîz in Harput ve Eğin kazalarıla mahdûd ..." şeklinde tarif edilmektedir. Yine aynı belgeden anlaşıldığına göre 1906 tarihinde Dersim Sancağı şu kazalardan oluş-

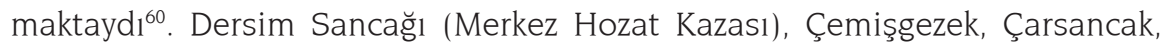
Mazgird, Kızılkilise (Nâzımiye), Ovacık ${ }^{61}$. H. 1325 (1907-1908) yıllarına ait idarî taksimat aynı olup, bu tarihte 1888 tarihinden itibaren bölgede oluşturulmağa başlanan nahiyeler idarî taksimat içerisinde dikkat çekmektedir ${ }^{62}$.

Dersim Sancağı idarî taksimat açısından, Osmanlı döneminin sonuna kadar; Hozat, Mazgird, Çemişgezek, Çarsancak, Kızılkilise (Nazımiye) ve Ovacık

55 H. 1310 Tarihli Ma'mûretü'l-Azîz Salnamesi, s.121.

56 BOA., Ylldız Tasnifi, Sadaret Resmi Mar. Ev. Dosya No: 54, Sira: 29, Belge: 4149.

57 BOA., Irade Dahiliye,9.CA.1310, Hususi : 19.

58 Ali Cevad, Memâlik-i Osmaniye'nin Tarih ve Coğrafya Lugatı, Cild-i Sâlis, İstanbul 1312, s.763-764.

59 Mehmed Zülfü, Dersim Tarihi, s.92.

60 BOA., Irade Dahiliye, 19. RA. 1324, Hususi: 26.

61 Ovacık Kazası: 1892 tarihinde lağvedilmiş olmakla beraber, daha sonra yine kaza olmuştur. 1908 yılında bir askerî kışla, 1910'da ise bir hükümet konağı yaptırılmıştır. 1916 tarihindeki olaylarda harap olmuştur. bkz. Mehmet Zülfü, Dersim Tarihi, s.92. 
kazalarını ihtiva etmekteydi. Yine idarî açıdan Dersim Sancağı Ma'mûretü'lAzîzVilâyeti'ne bağlı olma statüsünü Osmanlı Devleti'nin yıkılmasına kadar geçen süre içerisinde de sürdürmüştür ${ }^{63}$.

\section{Dersim Yolları}

Osmanlı hâkimiyeti süresince, Doğu bölgesinde, uzun bir dönem Dersim bölgesinin de bağlı olduğu Diyarbakır'ın ticarî yollar üzerinde önemli bir merkez olduğu görülmektedir. Diyarbakır-Bağdat yolu Osmanlı döneminde; 1-İstanbulİskenderun-Diyarbakır-Bağdat,2-Samsun-Diyarbakır-Mardin-Bağdat,3-İstanbulSivas-Diyarbakır-Bağdat bağlantılı idi. Söz konusu yolların XIX. yüzyılın sonuna kadar oldukça işlek olduğu bilinmektedir. Bu yoldan Bağdat tarafından gelen Hint malları, Diyarbakır üzerinden diğer bölgelere sevk edilmiştir. Bu yollara,1 İran veya Dağıstan-Diyarbakır-Sivas-İstanbul,2-İran veya Dağıstan-DiyarbakırHalep-Şam,3-İran veya Dağıstan-Diyarbakır-Bağdat yollarını da ilave etmek gerekir $^{64}$ (Bkz. Ek I. Diyarbakır'dan Geçen Ticaret Yolları Haritası).

Osmanlı döneminde, Dersim'in bu yollar güzergâhında bulunan önemli bir merkez olduğu söylenebilir. Dersim, ticari merkez olmamakla birlikte yukarıda zikredilen yol güzergâhları üzerinde önemli bir kavşak noktası olma durumundaydı. Doğudaki ulaşım ağı üzerinde önemli bir mevkie sahip olmakla birlikte, uzun bir dönem asayişin sağlanamaması ve arazi şartları sebebiyle Dersim bölgesi, her açıdan geri kalmıştır. Bu dönemde yazılan raporlarda da açıkça belirtildiği üzere(1896), Dersimlilerin eşkıyalık olaylarına karışmalarının başlıca sebebi, mahsullerini (odun ve kereste) satabilecek yerlere gönderip para kazanmayı yani ticareti bilmemeleri ve dişarıdan geçinmeye mecbur olmalarıdır. Özellikle aşiret reisleri ve seyyidlerin emir ve yasaklarına uyan halk, bunlar tarafından harice tecavüze sevk edilmiştir. Ancak yolların yetersiz olması sebebiyle asker gönderilmediği için, suçlular cezasız kalmış ve bu da uygunsuzlukları artırmıştır ${ }^{65}$.

63 BOA., Irade Dahiliye, 8-Z-1327, Hususi: 24, Irade Dahiliye, 23. N.1330, Hususi:25; Irade Dahiliye,16. N. 1332, Hususi : 12, Irade Dahiliye, 30.B. 1325, Hususi: 35.

64 Yılmazçelik, XIX. Yüzyılın İlk Yarısında Diyarbakır, s.314 - 315.

65 “... yolsuzluk belasıly kıta-i mezkure mahsulatı olan hatab ve kereste gibi şeylerin revaçlı mahallere sevkinden aciz olmalarından ve bu cihetle say ve amel ile para kazanmak yolunu ögrenemediklerinden dolayı ahalisilin nihayet varmış olan kemal-i fakir ve izdirarl ve idare-i maişetin tedarikinde zaruretlerin şedadid-i mevasime karşı devam ve istikrarı... ahad-l ahaliden pek çoğu klşın yiyecek erzak ve giyecek elbise bulamadıklarından bazen üstündeki ile imrar-l evkat itmeğe ve çırılçıplak mağara köşelerinde kışı geçirmeğe mecburiyet halinde olub pek çok nisvani giyecek elbise şöyle dursun setr-i avret idecek bir bez parçası bulamamakla üryan olarak arz-ı endam ittiği görülmüş̧ür...” . “...hariçten tadrik-i maişet yani icra-yı şekavet ihtiyacında olmalarıyla yalnız başına ahali-i mütiayata'addiiderek bir şey elegeçirmenin imkânsızlığı bunları mahafaza-i aşabiyete ve bir reis ve şeyhin emr ve nehyi altında bulundurmaya mecbur edü reis ise mukteziyat-l ahvalin kendisine verdiği nüfuz ve kadri kendi menfaatine istimal iderek fukara-yl ahaliyi gasb ve garete ve icra-yışekavete sevk itmekte ...” .BOA.,Ylldız Esas Arşivi, No:11004.

Akademik Bakış 233 Cilt 11 
Yine bu raporlarda yer alan ifadelerden anlaşıldığına göre, en kısa zamanda yolların yapılması istenmekteydi ${ }^{66}$.

Dersim Sancağı'nın oluşturulmasından sonraki dönemde, Osmanlı Devleti her şeyden önce bu bölgeye hâkim olmak için yolların açılmasına büyük önem verdiği görülmektedir.

\section{Dersim Bölgesinde Yol Yapım Çalışmaları}

Osmanlı döneminde, bir bölge veya şehrin iktisadî bakımdan gelişmiş olmasının başlıca şartı olarak, arazinin verimli yani ziraata elverişli olmasının yanı sıra ticaret yollarına yakın olması görülmekteydi. Yani ulaşım kolaylığı, yolların elverişli olması ticarî açıdan büyük bir öneme sahipti. Bu açılardan bakıldığında, Dersim bölgesinin arazî ve yol şartlarının uzun bir dönem elverişli olmadığı söylenebilir. Dersim Sancağı hakkında bilgi veren kaynaklar özellikle arazinin bu durumuna işaret etmişlerdir. 14 Mayıs 1906 tarihli bir arzda yer alan, “... kıt'a-i sağîre-i mezkûrenin bi-gâyet ârizalı ve ekseriyetle sengistân ve gayr-i kâbil-i zırâ'at bir hâlde bulunmasından dolayı ..." ifadesine Dersim ile ilgili bütün belgelerde tesadüf etmek mümkündür ${ }^{67}$.

Bundan da anlaşılacağı üzere, Dersim Sancağı'ndaki arazinin büyük bir bölümü ziraata uygun değildi. XX. yüzyıla ait kaynaklar, bölgede bulunan 7.000.000 dönüm arazinin 5.000.000 dönümünün zira'ata uygun olmadığını kaydetmektedir ${ }^{68}$. Osmanlı dönemine ait bilgiler de bunu doğrular mahiyettedir ${ }^{69}$. Dersim arazisinin, 1.500.000 dönümü ziraata uygun ve 500.000 dönümü ise ormanlık alanlardan meydana gelmekteydi ${ }^{70}$.

Arazinin oldukça dağlık ve güç şartları ihtiva etmesi, bölgede uzun bir dönem elverişli yolların yapılmamasına sebep olmuştur. Bu dönemde Batı Dersim mıntakası: Hozat, Çemişgezek, Ovacık ve Kemah kazalarını, Doğu Der-

661896 y1lına ait bu raporda; Erzincan-Ma'mûretü'l-Azîz yolunu birleştiren Hozat yolunun askerlerin yardımıyla inşasına başlanması ve Dersim ahalisinin bu yol yapımında çalıştırılması (yirmi para yevmiye ve yarım kıyye ekmek vermek suretiyle) istenmekteydi. BOA.,Yıldız Esas Arşivi, No:11004. Bu dönemde bölgede görev yapmıș olan kişilerin yazmış oldukları raporların tamamında, bölgenin kalkınabilmesi ve asayişin sağlanabilmesi için özellikle yol yapımına büyük önem verilmesi gerektiği bildirilmekteydi. Ayrıntılı bilgi için bkz. İbrahim Yılmazçelik, Osmanlı Devleti Döneminde Dersim Sancă̆l, Ankara, 2011, s.217-251.

67 BOA., Dahiliye Irade, 19.RA.1324, Hususi : 26; H. 1310 (1892-1893) Tarihli Ma'mûretü'l-Azîz Sâl-namesinde Dersim Sancağı tarif edilirken, “... Dersim arazisi çoğu kâbil-i zirâ'at bir kısmı sengistân, dağlar ormanlar ve meşeliklerden ibârettir ...” ifadesi yer alır. bkz. H. 1310 Tarihli Mâ'mûrâtü'l-Azîz Salnamesi, s.243. 9 Haziran 1908 tarihli bir arzda, “... Dersim havalisi ekseriyetle sengistândan ibâret ve gayr-i kâbil-i zırâ'at yerler olmakla ...”. bkz. BOA., Irade Dahiliye, 9. CA.1326, Hususi : 11.

68 Dahiliye Vekâleti, Jandarma Umum Komutanlığı. Dersim, s.50.

69 Şemsettin Samî, “Dersim”, Kâmûsü'l-Alâm, C. III, İstanbul, 1307, s.2131-2132. Şemsettin Samî, Dersim toprağının büyük bir bölümünün ziraatta elverişsiz dağlık ve taşlık bir arazi olduğunu ve ayrıca ormanların da fazla olduğunu kaydetmektedir.

70 Dah. Vek. Jan. Umum Kom, Dersim, s.50. 
sim mıntıkası ise: Mazgirt, Kığı, Çarsancak (Pertek, Peri) Nazimiye ve Pülümür kazalarını ihtiva etmekteydi. Bu bölge içerisinde bazı kazalar hariç ve özellikle “ Dersim İçi “ denilen iç kesimlerde uzun süre yüklü hayvanların bile geçebileceği bir yol bulunmamaktaydı.

Osmanlı Devleti, Dersim Sancağı'nın 1848 tarihinde teşkil edilmesinden hemen sonra bölgede yol yapımına girişmiştir. Bu bölgede ilk yapılan yol, Hozat-Erzincan yolu olup, bu yol Hozat ile Mercan Boğazı arasındaki yolu kap-

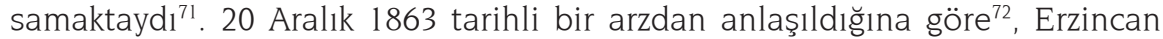
Sancağı'nın Dördüncü Ordu merkezi yapılmasından hemen sonra (1860-1863), Dersim Sancağı içerisinde yeni bir yol yapılması emredilmişti. Buna göre söz konusu yol güzergâhı ise şöyle idi.

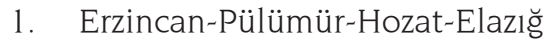

2. Erzincan-Pülümür-Nazımiye-Mazgirt-Elazı ğg

3. Ovacık-Erzincan

20 Aralık 1863 tarihli arzda belirtildiği üzere, Harput ve Diyarbakır tarafından Erzincan'a giden yol, Dersim Sancağı'ndan geçmiyor ve Harput-Erzincan yolu 60 saatlik bir mesafeyi ihtiva ediyordu. Yeni yolların yapılması ile bu mesafenin 30 saate düşürülmesi hedeflenmekteydi. Tahminen 1860 tarihinde söz konusu yolların yapılmasına başlanmış ve Harput-Hozat yolu üzerinde gerekli yerlere kârgîr köprüler de yapılmak üzere ${ }^{73}$, bu yol 13 Kasım 1862 tarihinde tamamlanmışt1 ${ }^{74}$. Ancak Dersimdeki aşiretler, itaat altına girmek istemedikleri için, sancak civarındaki yolları tahrip etmişlerdir. Buraların yeniden devletin kontrolü altına alınabilmesi amacıyla IV. Ordu görevlendirilmişti. Askeri açıdan önemli olan Harput-Dersim-Hozat ${ }^{75}$ yolunun bakım ve onarım çalışmalarına 1867 tarihinde yeniden başlanılmıştı ${ }^{76}$.

Hozat-Erzincan yolu, Hozat ile Mercan Boğazı arasındaki yolu ihtiva etmekteydi. Bu yolun yapımı civar aşiretlere ihale edilmişti. Buna göre yolun yapımında çalışanlara amelelik ücreti ödenecek, ancak diğer giderler aşiretler ve civar kazalardan karşılanacaktı. Buna karşılık Dersim Sancağı on sene boyunca vergiden muaf tutulacaktı. Hozat-Erzincan yolunun Mercan Boğazı yakınlarında Ayvaz Tarlası denilen kısma kadarki 18 saatlik yolun yapımını aşiretler üst-

71 BOA., Irade Dahiliye, No:515-35071.

72 BOA., Irade Dahiliye, No: 35376.

73 “....Hozat'dan Mercan Boğazına kadar yapılan yollarda ceryan eden sular üzerinde inşa kılınan 9 aded köprünün 8 adedi tarafeyni kullanıkl ve etrafi parmaklı ve yağmur suyundan bozulub çürümemek üzere yağll boyalı ve diğer 1 aded yine Munzur suyu denilen nehr-i kebir üzerinde kargir ve üstünün döşemesi ahşab ev 3 gözlü olarak yapılub fakat işbu köprü şiddet-i şitadan harç kabul etmemeğe başladı̆̆ından bunun ikmali dahi evvel bahara...” bırakılmıştı. BOA., Irade Dahiliye, No:515-35071.

74 BOA., Irade Dahiliye, No: 35376.

75 BOA., I.DH. 950/75198, 26 Receb 303/30 Nisan 1886.

76 BOA., I-DH. 558/38901, 8 Şevval 1283/13 Şubat 1867.

\section{gor}

Akademik Bakış 235 Cilt 11 Sayl 21 Kış 2017 
lenmişti. Buradan Erzincan'a kadar olan yol ise Kemah, Gürcanis, Çarsancak kazalarına ihale edilmişti. Ancak 1863 tarihli arzdan anlaşıldığına göre, yolun önemli bir bölümü inşa edilmiş olmakla beraber her iki taraftan da yarım saatlik bir yol kalmış olduğu halde, kışın gelmesiyle ${ }^{77}$ yol yapımına ara verilmişti ${ }^{78}$. Bu arada Hozat'tan Mercan Boğazı'na kadar olan yol üzerinde 9 adet köprü inşasına başlanmıştı. Munzur Suyu üzerindeki köprü ise daha büyük olarak inşa edilmeğe başlanmış, ancak kışın gelmesi ile bu köprünün yapımı da yarım bırakılmıştı ${ }^{79}$.

Dersim Sancağında eşkıyalık olayları devamlılık arz ettiğinden, devlet yol güzergâhı boyunca 1867 yılında büyük bir kışlanın inşa edilmesine karar vermiştiti ${ }^{80}$ Yukarıda da belirtildiği üzere, Dersim Sancağı'nın 1848 tarihinde teşkil edilmesinden hemen sonra bölgede yol yapımına girişilmiş ve Erzincan Sancağının Dördüncü Ordu merkezi yapılmasından hemen sonra (1860-1863), Dersim Sancağı içerisinde yeni bir yol yapılması emredilmişti. 16 Mayıs 1871 tarihli bir belgeye göre bu yollar tamamlanamamış olup; söz konusu belge bu konuda ayrıntılı bilgiler vermektedir ${ }^{81}$.

Buna göre; Erzincan'dan Dersim Dağları üzerinden geçirilerek, Kızılkilise’ye (Nazımiye) ve oradan bir kolu Diyarbekir ve diğer kolu Mamuretü'l-aziz'e ulaşmak üzere yeni bir yol yapılması, IV. Ordu Müşiri tarafından istenmiş, Erzurum Vilayeti Yol komisyonunca da uygun bulunmuş ve Devlet tarafından da onaylanmıştı. Böyle bir yolun açılması Erzurum-Bağdat ve Trabzon taraflarıly olan uzaklığı 40-50 saat azaltacaktıㄹ. Bunun için 8 bin kise masraf yapılması gerekmekteydi. Öncelikle Mamuretü'l-aziz-Erzincan arasındaki yolun yapımına başlanacak, burası tamamlandıktan sonra Palu-Diyarbakır yoluna başlanacaktı. Bu sebeple ilk etapta 2 bin kiseye ihtiyaç bulunmaktaydı. Diyarbakır, Erzincan ve Mamuretü'l-Aziz bölgesinden "amele ve hayvan ile araba" temini zor olmamakla birlikte, Dersim'den vergi toplamak hayli güç olacaktı. Bununla birlikte

77 H. 1310 (1892-1893) tarihli Ma'mûretü'l-Azîz Salnâmesinde, Dersim Sancağı'nda kışın çok sert ve uzun geçtiği, yolların kapandığı ve kışın yaklaşık 5-6 ay devam ettiği kaydedilmektedir. $H$. 1310 tarihli Ma'mûretü'l-Azîz Salnamesi, s.243. Bölgede kışın oldukça sert geçtiği hakkında ayrıca bkz. Şemsettin Sami, “Dersim”, Kâmûsü'l-Alam, C. III, s.2131 - 2132.

78 BOA., Irade Dahiliye, No: 35376.

79 “... Hozat'dan Mercan Boğazı’na kadar yapılan yollarda cereyân iden sular üzerinde inşâ kılınan dokuz 'aded köprünün sekiz 'adedi tarafeyni koltuklı ve etrâfi mukallaklı ve yağmur suyundan bozulub çürimemek üzere yağll boyall ve diğer bir 'aded yani Munzur Suyu dinilen nehr-i kebîr üzerinde kargîr ve üstünün döşemesi ahşâb ve üç gözlü olarak yapılub fakat işbu köprü şiddet-i şitâdan harc kabul itmemeğe başladığından bunun ikmâli dahî evvel bahara ta'lik idilmiş..." BOA., Irade Dahiliye, No: 35376.

80 BOA., $\dot{I}-D H .558 / 38901,8$ Şevval 1283/13 Şubat 1867.

81 BOA., I-MMS. 41/1688, 25 Safer 1288/16 Mayis 1871.

82 “...Bağdad caddesinin şimdiki güzergâhının Samsun ile Diyarbekir şehri beyni 150 saat olduğu halde yolcunun Erzincan'a tevcîhleri takdirinde Diyarbekir'den Erzincan'a 55 ve Erzincan 'dan Trabzon'a 48 ki cemân 103 saatde sahil-i bahre vüsûl ile berren 47 saat kazanılacağına...". BOA., İ-MMS. 41/1688. 
takdim edilen haritalardaki yolların bir an önce tamamlanması istenmekteydi ${ }^{83}$ (Bkz. EKII. 16 Mayıs 1871 Tarihli Belgenin Ekindeki Harita).

Öte yandan yukarıda söz konusu edilen yollardan ayrı olarak, ErzincanOvacık arasında başka bir yol yapımına da yine bu dönemde başlanmıştı ${ }^{84}$ (Bkz. EK III. 1 Mart 1289 (13 Mart 1873 Tarihli Harita). 13 Mart 1873 tarihinde Erkân-1 Harb Kolağası Mehmed İzzed'in hazırladığı haritadan anlaşıldığına göre, Osmanlı devleti, Dersim Sancağında hâkimiyetini tahsis etmek için Pülümür-Çarsancak arasına pek çok askeri kule(Karakol) yaptırmıştır. Yine 13 Mart 1873 tarihli haritadan anlaşıldığına göre, Türüşmek ( Tunceli il merkezine 11 kilometre mesafede) nahiyesi civarına 3 adet büyük karakol yapılmasına karar verilmiş ve bu iş için 21.400 kuruş ayrılmıştı ${ }^{85}$. Dersim sancağına bağlı Peri Kasabasında Kığı Suyuna yapılacak köprünün yakınına ise 5 adet küçük karakol yapılacaktı. $\mathrm{Bu}$ iş için de 18.400 kuruş ayrılmıştı. Yine bu haritadan anlaşıldığına göre, yapımına başlanan yolların büyük bir kısmı tamamlanamamıştır ${ }^{86}$.

Yapımına 1860 tarihinden hemen sonra başlanmış olmakla birlikte, bölgede yapımına başlanan yollardan sadece, Harput-Pertek arasındaki yolun bir kısmı bitirilmiş, diğer yollar ise yapılamamıştır ${ }^{87}$ (bkz. EK IV.1883 Tarihli Harita.) . 1860 tarihinde yol yapımı için İsmail Hakkı Paşa ve Erzurum Müşiri Semih Paşa, Dersim'deki aşiret reislerini Erzurum'a davet etmişler ve bunlardan söz almışlard1 ${ }^{88}$. Bu toplantıya Dersim aşiretlerinin önde gelen reisleri iştirak etmiş, ancak daha sonra aşiretler anlaşmazlığa düşmüşler ve Gülabî Ağa'nın öldürülmesi ile yol yapımında aşiretlere mensup insanları çalıştırmak mümkün olmamıştır ${ }^{89}$.

Dersim bölgesindeki aşiretlerin bir türlü itaat altına alınamaması, bölgede yapılmak istenen yolların bitirilememesine sebep olmuştur. "Mart 1909 (9 Safer 1327) tarihli Meclis-i Vükela mezakeratına mahsus zabt varakasından anlaşıldığına göre, bu tarihlerde Harput-Erzincan yolu tamamlanamamıştı ${ }^{90}$. Yine, Asya-yı Osmaniye'de H.1327 (1909-1910)/ H.1329 (1911) tarihleri arasında inşa veya tamir edilen yolları gösterir haritadan anlaşıldığına göre ${ }^{91}$, Dersim Bölgesindeki yollar tamamlamıştı. (bkz. EK. V Asya-yı Osmaniye'de H.1327 (1909-1910)/ H.1329 (1911) Tarihleri Arasında İnşa Veya Tamir Edilen

83 BOA., I-MMS. 41/1688, 25 Safer 1288/16 May1s 1871.

84 BOA., Irade Dahiliye, No: 35376.

85 Bkz. Ek. III 1 Mart 1289 ( 13 Mart 1873) Tarihli Harita. BOA., HRT. 1897.

86 BOA. HRT. 1897.

87 Bkz. Ek. IV 1883 Tarihli Harita. BOA. HRT. 1609.

88 Dah. Vekâleti., Jan. Umum Kom. Dersim, s.73.

89 BOA., Irade Dahiliye, No: 35376. 1903 tarihinde Dersim'in durumu ile ilgili bir rapor yazan Arifi Paşa, bölgedeki ıslahatların başarılı olması için Erzincan-Ovacık-Hozat-Harput yolunun inșa edilmesi ve Fırat Nehri üzerine de bir asma köprü yapılmasının şart olduğunu kaydetmiştir.. Dah. Vekâleti, Jan. Umum. Kom. Dersim, s.74-193.

90 BOA., $M V .125-82$.

91 BOA., HRT. 1828.

Akademik Bakış 237 Cilt 11 
Yolları Gösterir Harita). Zira Dersim'den geçen Harput(Mezraa) - Erzincan yolu, haritada kırmızı renkle gösterilen “...1326 (1908) - 1328 (1911) seneleri zarfında müceddeden veya tamirat-1 esasiye suretiyle inşa ve ikmalleri teklif olunan..." yollar arasında gösterilmektedir. Yine Dersim bölgesinden geçen Harput(Mezraa) - Erzurum yolunun Harput- Kı̆̆ı arası, haritada yeşil renkle gösterilen “... tarik-1 umumiye programına ilaveten idhal olunan..." yollar arasında gösterilmektedir. Bu da her iki yolun tamamlanmadığını göstermektedir 92.

\section{Sonuç}

Dersim Sancağı'nın oluşturulmasından sonra, uzun bir dönem devlet otoritesinden uzakta yaşayan bir kısım aşiret reisleri ve seyyidler, bölgede yapılmak istenen yeni uygulamaların kendi hâkimiyetlerinin zayıflayacağını anlamışlar ve devamlı surette buna karşı çıkmışlardır. Devletin yanında görünen bir kısım aşiret reisleri de, bu niyetlerinde bir türlü samimi olmamışlardır. XIX. yüzyılın ikinci yarısında Dersim Sancağı'nın iktisadî durumu iyi olmamasına rağmen, bu durumu düzetmek için bu bölgeye yapılmak istenen yollar, bölgede devlet denetimini artıracağı endişesi ile aşiretler tarafından devamlı suretle engellenmiştir.

XIX. yüzyılın sonlarında Osmanlı devletinin her açıdan oldukça zor şartlar altında bulunduğu bilinmektedir. Devlet içeriden ve dişarıdan büyük bir kuşatma altında kalmıştır. Bütün bunlara rağmen, özellikle II. Abdülhamid döneminde başlatılan bayındırlık faaliyetlerinin büyük bir gelişim kazandığı görülmektedir. Bu gelişim kendisini yol ve geçitlerin yapılması ve buna bağlı olarak nehirler üzerinde köprülerin inşa edilmesi sahasında da göstermiştir. Ancak 1908 tarihinden sonra bu çalışmalar büyük bir kesintiye uğramış ve birkaç sene sonra da tamamen durmuştur. Balkan Savaşları ve I. Dünya Harbi de bu çalışmaların tamamen durmasının bir diğer sebebi olmuştur. Bu alanda yapılan çalışmalara 1925 tarihinden sonra ancak başlanabilmiştir. Dersim bölgesinde bulunan yolların büyük bir kısmı, Cumhuriyet Dönemi'nde yapılmıştır.

\section{Kaynaklar}

\section{I-Arşiv Kaynakları}

\section{Başbakanlık Osmanlı Arşivi}

A. MKT, MVL, Dosya: 10, Sira: 85.

Cevdet Dâhiliye, No:13142; No: 14542

Cevdet Maliye, No: 9377.

D. CRD, Genel: 40719, Özel: 848

Dâhiliye İrade, 19.RA.1324, Hususi: 26;15.CA.1316, Hususi: 36, 19. RA. 1324, Hususi: 26, 23. N.1330, Hususi:25;30.B. 1325, Hususi: 35; 8-Z-1327, Hususi: 24;

92 BOA., HRT. 1828. 
9. CA.1326, Hususi: 11; 9.CA.1310, Hususi: 19; 16. N. 1332, Hususi: 12. HRT. 1609;HRT. 1828;HRT. 1897.

İ-MMS. 41/1688;41/1688.

İrade Dâhiliye, No: 558/3890; No: 950/75198, No: 11639; No: 13263; No: 18356; No: 2361 1; No: 28195; No: 26038; No: 35376; No:515/35071.

İrade Meclis-i Vâlâ, No: 14863, No: 20339; No: 3957; No: 11388, No: 13735; No: 15294; No: 18061; No: 18363; No: 18501; No: 19229; No: 20503; No: 5817; No: 7106; No: 8431; No:18357; No: 3542.

İrade Mevadd-1 Dâhiliye, No: 39457.

Maliyeden Müdevver, No: 13190;

ML.VRD, No: 2335; No: 3057;

MV. 125-82

Yildız Esas Arşivi, No: 11004.

Yildız Tasnifi, Sadaret Resmi Mar. Ev. Dosya No: 54, Sira: 29, Belge: 4149

Mecmua-1 Umur-u Nafia, H. Fi Muharrem 1302 (Ekim-Kasım 1884)

Mecmua-1 Umur-u Nafia, H. Fi Cemaziyel-ahir 1302 (Mart-Nisan 1885)

\section{Salnameler}

H. 1301- H. 1310- H. 1312- H. 1325 Tarihli Ma'mûretü'l-azîz Salnamesi

\section{Tetkik Ve Genel Eserler}

AKSOY, Bilal, Tarihsel Değişim Sürecinde Tunceli, Ankara 1985.

Ali Cevad, Memâlik-i Osmaniye'nin Tarih ve Coğrafya Lugatı, Cild-i Sâlis, İstanbul 1312. BAYKARA, Tuncer, Anadolu'nun Tarihi Coğrafyasına Giriş I, Ankara 1988.

ÇADIRCI, Musa, “ Tanzimat'ın Uygulanması ve Karşılaşılan Güçlükler (18401856) “, Mustafa Reşid Paşa ve Dönemi Semineri Bildiriler, Ankara 1985.

Dersim, T.C. Dâhiliye Vekâleti Jandarma Umum Kumandanlığı III, IKS-Sayı: 55058.

GÖYÜNÇ, Nejat, “ Diyarbakır Beylerbeyliğinin İlk İdari Taksimatı “, İstanbul Ün. Edebiyat Fak. Tarih Dergisi, Sayl: 23 (1969).

KODAMAN, Bayram, Osmanlı Devrinde Doğu Anadolu'nun İdari Durumu, Ankara 1986. KUNT, Metin, Sancaktan Eyalete, İstanbul, 1978.

SEVGEN, Nazmi, Doğu ve Güneydoğu Anadolu'da Türk Beylikleri, Ankara 1982.

Şemsettin Sami, “ Dersim “, Kamûsü l-Alâm, C. III, İstanbul, 1307.

ŞEREF HAN, Şeref-nâme, Çev. Mehmet Emin Bozarslan, İstanbul 1975.

TIZLAK, Fahrettin, Keban ve Ergani Yöresinde Madencilik, Firat Ün. Sosyal Bil. Ens. Yayınlanmamış Doktora Tezi, Elazı̆̆ 1991.

TÖNÜK, Vecihi, Türkiye'de İdari Teşkilatın Tarihi Gelişimi ve Bugünkü Durumu, Ankara 1945 ÜNAL, Mehmet Ali, XVI. Yüzyılda Harput Sancağı, Ankara 1989.

YILMAZÇELIK, İbrahim, “1840-1850 Yıllarında Harput”, Türk Dünyası Araştırma- 
ları Dergisi, Sayı: 52

YILMAZÇELIK, İbrahim, Osmanlı Devleti Döneminde Dersim Sancağı, Ankara, 2011. YILMAZÇELIK, İbrahim, XIX. Yüzyılın İk Yarısında Diyarbakır, Ankara 1995.

YOLGA, Mehmet Zülfü, Dersim (Tunceli) Tarihi, (Yayına Hazırlayanlar: Ahmet Halaçoğlu, İbrahim Yılmazçelik), Ankara 1994.

\section{EKLER}

EK: I Osmanlı Hâkimiyeti Süresince Ticaret Yolları (Diyarbakır'dan Geçen Ticaret Yolları )( İbrahim Yılmazçelik, XIX. Yüzyılın İlk Yarısında Diyarbakır, 1790-1840 (Fizikî, İdarî ve Sosyo-Ekonomik Yapı) Ankara,1995.)

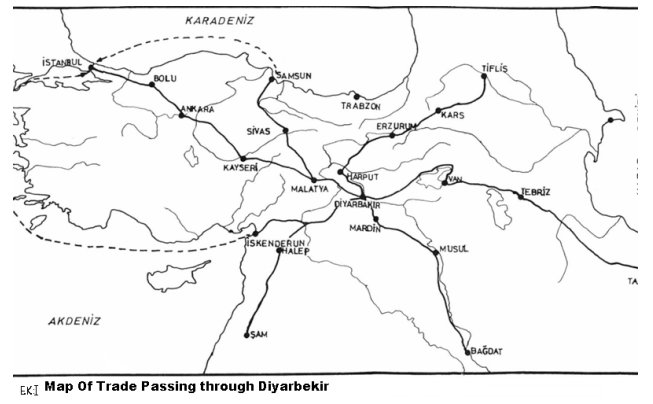

EK II. 16 Mayıs 1871 Tarihli Belgenin Ekindeki Harita (BOA. İ-MMS. 41/1688, 25 Safer 1288/16 Mayıs 1871)

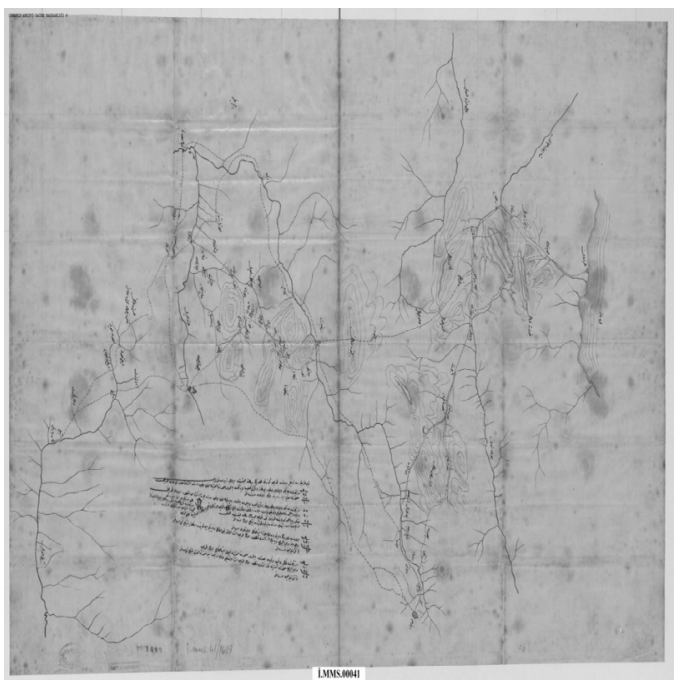

HARITA ÜZERINDE YAZAN BILGİ: BOA. İ-MMS. 41/1688, 


\begin{tabular}{|c|c|}
\hline Saat & \\
\hline 332 & $\begin{array}{l}\text { Erzincan'dan Caniğ'e ve Pülümür ve Dar Boğaz ve Kızılkilise ve Pertek'den } \\
\text { bi'l-mürûr Mamuratü'l_aziz'e müntehî olmak üzere inşası mutasavvır bulu- } \\
\text { nan tarık }\end{array}$ \\
\hline 228 & Mamuratü'l-aziz ile Diyarbekir beyninde olan mesafe \\
\hline \multicolumn{2}{|l|}{++60} \\
\hline 555 & $\begin{array}{l}\text { Erzincan'dan Caniğ'e ve Pülümür ve Dar Boğaz ve Kızılkilise ve Paludan } \\
\text { bi'l-mürûr Diyarbekir'e müntehi olmak üzere mücedden inşası mutasavvır } \\
\text { olan tarık }\end{array}$ \\
\hline 220 & $\begin{array}{l}\text { Erzincan'dan ......ve Havcücü ve Kırıklı karyelerinden bi'l-mürur Erzu- } \\
\text { rum ile Trabzon beyninde inşa olunan tarı üzerinde vak'ı Pir Ahmed } \\
\text { Köprüsü'ne Müntehî Tarık// saat 55/Erzincan ile Diyarbekir } 17 \text { Erzincan'dan } \\
\text { Kızılkiliseye kadar birlikde gidecek tarık inha mücedden inşası mürur-u } \\
\text { müşkilat+38 }\end{array}$ \\
\hline 228 & $\begin{array}{l}\text { Mezkûr Pir Ahmed Köprüsü'nden Trabzon'a kadar tarık-ı cedîdin saat cin- } \\
\text { sinden tulu }\end{array}$ \\
\hline+103 & $\begin{array}{l}\text { Erzincan'dan mürûr etmek üzere Diyarbekirle Trabzon beyninde olan me- } \\
\text { safe }\end{array}$ \\
\hline 1150 & $\begin{array}{l}\text { El-yevm mârrin-i âbirînin Diyarbekir'den Samsun'a işlemekde oldukları } \\
\text { mesafe }\end{array}$ \\
\hline 1103 & $\begin{array}{l}\text { Ber-vech-i bâlâ Dersim içinden Diyarbekir'e kadar küşâdı mutasavvır olan } \\
\text { tarık inşa olunduğu halde Diyarbekir ile Trabzon iskelesi beynindeki mesafe }\end{array}$ \\
\hline-47 & Berren Kazanılacak mesafe \\
\hline 660 & $\begin{array}{l}\text { Erzincan'dan Kemah ve Eğin ve Keban madeninden bi'l-mürur Mamuratü'l- } \\
\text { aziz'e el-yevm işlemekde olan tarık }\end{array}$ \\
\hline 332 & $\begin{array}{l}\text { Dersim içinde Mamuratü'l-aziz'e kadar küşâdı mutasavvır olan tarık inşa } \\
\text { olunduğu halde Erzincan ile Mamuratü'l-aziz beynindeki mesafe }\end{array}$ \\
\hline-28 & Berren kazanılacak mesafe \\
\hline
\end{tabular}

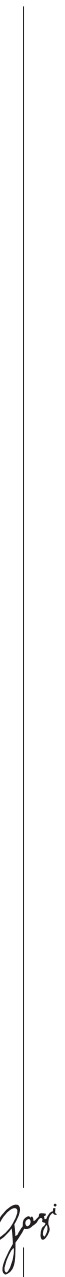

Akademik Bakış 241 
Ek: III 1 Mart 1289 ( 13 Mart 1873) Tarihli Harita (BOA.HRT. 1897)

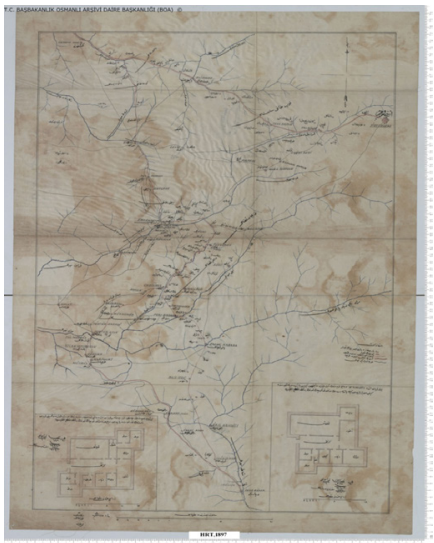

Ek: IV 1883 Tarihli Harita. BOA. HRT.11609.

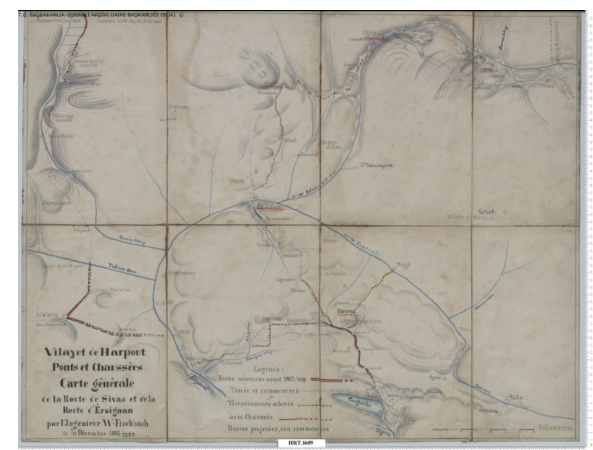

EK. V Asya-yı Osmaniye'de H.1327 (1909-1910)/ H.1329 (1911) Tarihleri Arasında İnşa Gori Veya Tamir Edilen Yolları Gösterir Harita (BOA. HRT. 1828).

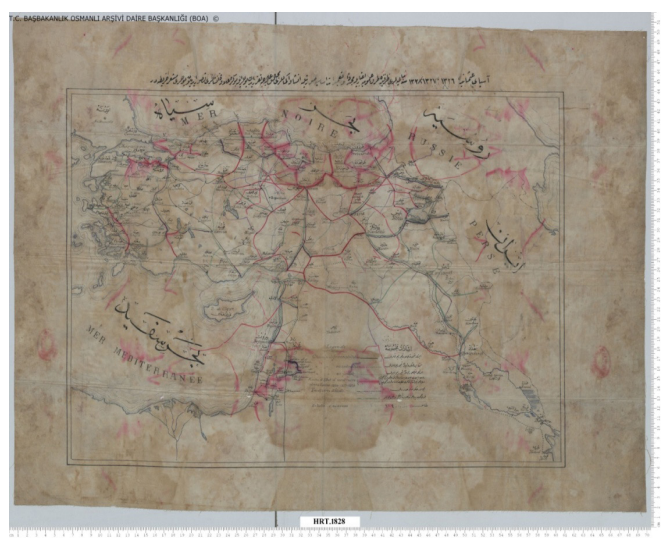




\section{Extended Abstract}

During the Ottoman domination it is seen that Diyarbakir where the Dersim region is also connected for a long period, was an important center on the commercial roads. It can be said that Dersim, which is connected to Diyarbakır province, was an important center on the route of these roads. Dersim was not a commercial center but had to be an intersection point on the roads passing through the eastern region. The Dersim region which was an important route on the transportation network in the east has been backward from all angles due to the lack of public order and land conditions for a long period of time. As it is clearly stated in the reports of the Ottoman period, the main reason why the people of Dersim were involved in banditry events is that they did not know where they can sell their crops (wood and timber) and make money. Especially, local people who follow orders and prohibitions of tribal chiefs and the seyyids, they have been referred to the rape. However, since the soldiers were not sent because the roads were inadequate, the accused remained unpunished and this increased the inconveniences. According to the statements in these reports, it was understood that roads should be constructed as soon as possible.

In the period after the formation of Dersim Sanjak, the Ottoman Empire gave great importance to opening up roads to dominate this region before anything else. After the foundation of the Dersim sanjak, some tribal chiefs and seyyids who lived away from the state authority for a long time realized that their own dominance of the new practices to be made in the region would weaken and they opposed it all the time. Some tribal chiefs who appear beside the state have not been sincere in their intentions. Despite the fact that the economic situation of Dersim Sanjak was not good in the second half of the 19th century, the ways to build this region to rectify this situation were constantly hampered by the tribes with the concern that they would increase state control in the region.

It is known that at the end of the 19th century the Ottoman state was under very difficult conditions in all respects. The state was under great siege from inside and outside. Despite all these, especially in the activities of public works initiated during the period of the Abdulhamid the Second, have developed a great deal. This development has also shown itself in the way of construction of roads and passageways and accordingly the construction of bridges over rivers. However, after 1908 these studies were severely interrupted and stopped a few years later. The Balkan Wars and the First World War were another reasons for these efforts to cease altogether. Therefore, a large part of the roads in the Dersim region were constructed during the Republican Period.

Akademik Bakış 243 Cilt 11 Sayı 21 Kış 2017 